\title{
Don't Tell Juries About Statutory Damage Caps: The Merits of Nondisclosure
}

\author{
Michael S. Kang $\dagger$
}

It has become increasingly common for Congress and state legislatures to enact statutory limits on the amount of money damages that a plaintiff can recover in a jury trial. Most of these statutory caps limit awards for noneconomic compensatory damages in certain civil actions such as malpractice, personal injury, and wrongful death. Federal courts and most state courts have ruled that statutory caps do not violate the constitutional right to a jury trial in civil cases. ${ }^{1}$ Although a minority of courts have decided otherwise, most courts construe the caps as rules of law to be applied by the court without jury involvement. ${ }^{2}$

Reflecting fears that knowledge of the caps might affect jury judgments, some statutes that provide for caps also prohibit notifying the jury about the existence of these caps. One concern is that juries, once informed about the effect of the cap, might try to evade it. For example, in Sasaki v Class, ${ }^{3}$ the court concluded that there was "strong reason to believe that the jury," once it learned of the existence of the damage cap, attempted to compensate the plaintiff fully by awarding more damages for the counts that were uncapped. ${ }^{4}$ Another concern is that juries might calibrate their awards against the cap figure, using the cap as a standard for measurement. Knowledge of the dollar amount of the cap might thereby press the jury's damage assessment upward or downward. ${ }^{5}$ While there has been much debate and liti-

† B.A. 1993, The University of Chicago; M.A. 1996, University of Mlinois; J.D. Candidate 1999, The University of Chicago.

1 Courts distinguish between a jury assessment of damages and the application of the cap to that assessment. The plaintiff is entitled to have the jury make an assessment of damages under the right to a jury trial, but has no right to receive that sum if the law limits those damages to a lesser figure. See Part I.

${ }^{2}$ See, for example, Etheridge $v$ Medical Center Hospitals, 237 Va 87, 376 SE2d 525, 529 (1989) (" $[$ A]lthough a party has the right to have a jury assess his damages, he has no right to have a jury dictate through an award the legal consequences of its assessment.").

392 F3d 232 (4th Cir 1996).

- Id at 237.

${ }^{5}$ The legitimacy of each concern-evasion of caps and calibration of awards against caps-is supported by a distinct body of empirical research. The research establishes that in either scenario, a jury might award an amount different from what it would have without disclosure-a difference not attributable to the merits of the case. See Part II for a 
gation over the constitutionality of statutory caps, courts and commentators have largely neglected the nondisclosure issue. Courts have enforced nondisclosure statutes where they exist, but they have allowed disclosure of damage caps in cases of statutory silence.

In the near future, nondisclosure issues may receive more attention. As cases like Sasaki, in which the plaintiff's attorney disclosed the damage cap during closing argument and the jury appeared to increase its award to circumvent the cap, ${ }^{6}$ become more common, plaintiffs may begin to request instructions disclosing statutory caps, or they may disclose the caps themselves. Alternatively, defendants might seek disclosure if they think that juries will measure their awards against the caps, thereby pushing the awards downward. In either case, however, the jury award would be distorted without regard to the underlying merits of the case.

This Comment argues that courts should adopt a policy of nondisclosure of statutory caps even where statutes are silent on the issue. Part I briefly outlines the caselaw on nondisclosure of statutory caps and then explains that nondisclosure is consistent with the reasoning used by courts to uphold the constitutionality of the statutory caps themselves. Part II argues that prohibiting disclosure of statutory damage caps serves powerful public policy interests. Nondisclosure prevents distortions of jury awards and helps to ensure the integrity of jury findings.

\section{CURRENT LAW REGARDING NONDISCLOSURE OF STATUTORY CAPS}

\section{A. The Legislative Intent Behind Statutory Caps and Nondisclosure}

In response to concerns about excessive damage awards by runaway juries, Congress and state legislatures have imposed statutory limits on damages for some causes of action. ${ }^{7}$ These

more detailed discussion of the problem of distorted awards.

692 F3d at 235-36.

7 For discussions of tort reform efforts nationwide, see Andrea Moore Hawkins, Note, Balancing Act: Public Policy and Punitive Damages Caps, 49 SC L Rev 293, 303-09 (1998) (discussing legislative efforts in Colorado and South Carolina); Marshall S. Turner and Andrew T. Houghton, Punitive Damages Reform Moves to the State Arena, 18 Natl L J B7 (July 29, 1996) (discussing damage caps in Illinois and Texas and noting the enactment of caps in at least thirteen other states); Kathleen E. Payne, Linking Tort Reform to Fairness and Moral Values, 1995 Det Coll L Rev 1207, 1215-36 (reviewing tort reform efforts, including damage caps, in automobile insurance, medical malpractice, and products liability law); Robert L. Haig and Steven P. Caley, Successfully Defending Products Liability Cases, 5 Fed Litig Guide Rptr 693, 695 (Nov 1995) (noting the existence of caps on noneconomic 
caps represent a legislative attempt to limit the ability of irresponsible juries to award excessive damages. One congressman argued that "there must be a limit put on punitive damages, particularly when they are imposed on defendants in a reckless manner by vindictive juries." ${ }^{8}$ As one commentator observed, "The impetus for these statutory caps seems to be the perception that 'runaway juries' are threatening the economic viability of health care, business, and insurance."

One such statutory cap at the federal level appears in the Civil Rights Act of 1991, which limits the compensatory and punitive damages that can be awarded "for future pecuniary losses, emotional pain, suffering, inconvenience, mental anguish, loss of enjoyment of life, and other nonpecuniary losses."10 A supporter of this particular cap on damages explained that it was necessitated by the "fear of the business community of compensatory and punitive damages. $* * *$ Everybody worries about a runaway jury."11

Many state legislatures have imposed similar limits on noneconomic damages for certain types of suits. ${ }^{12}$ Fears about rising insurance rates for personal injury and medical malpractice have driven legislative action to cap damage awards across the country. For example, the California Medical Injury Compensation Reform Act provides that "[i]n any action for injury against a health care provider based on professional negligence, the injured plaintiff shall be entitled to recover noneconomic losses," but "[i]n no action shall the amount of damages for noneconomic losses exceed two hundred fifty thousand dollars $(\$ 250,000) .{ }^{p 3}$

damages in almost twenty states); Paul B. Weiss, Comment, Reforming Tort Reform: Is There Substance to the Seventh Amendment?, 38 Cath U L Rev 737, 740-46 (1989) (noting the emergence of caps on noneconomic damages and assessing their resilience against constitutional challenges).

${ }^{8} 141$ Cong Rec H 2655 (Mar 6, 1995) (remarks of Rep Norwood).

9 Colleen P. Murphy, Determining Compensation: The Tension Between Legislative Power and Jury Authority, 74 Tex L Rev 345, 347 (1995).

${ }^{10} 42$ USC \& 1981a(b)(3) (1994).

1137 Cong Rec S 29041 (Oct 30, 1991) (remarks of Sen Bumpers).

${ }^{12}$ See, for example, Alaska Stat $\S 09.17 .010(a)$-(b) (1996) (limiting personal injury awards); Cal Civ Code $\S 3333.2$ (West 1986) (limiting medical malpractice awards); Fla Stat $\S 766.207$ (7) (Supp 1988) (limiting arbitration awards); Idaho Code $\S$ 6-1603 (1998) (limiting personal injury awards); Kan Stat Ann \$ 60-19a02 (Supp 1998) (same); Md Cts \& Jud Proc Code Ann § 11-108(b) (Supp 1997) (same); Mich Comp Laws $\$ 600.1483$ (1996) (limiting medical malpractice awards); Minn Stat Ann § 466.04 (West Supp 1998) (limiting liability of municipality); Mo Rev Stat $\S 538.210$ (1991) (limiting medical malpractice awards); Or Rev Stat § 18.560 (1995) (limiting personal injury awards); W Va Code § 557B-8 (1994) (limiting medical malpractice awards).

${ }^{13}$ Cal Civ Code $\S 3333.2$. Another example is Va Code $\$ 8.01-38.1$ (1987), which limits recovery of punitive damages for medical malpractice:

In no event shall the total amount awarded for punitive damages exceed $\$ 350,000$. 
In addition to capping the damage award, legislatures often stipulate by statute that the court should not permit disclosure of the statutory cap to the jury. The 1991 Civil Rights Act specifically bars courts from telling juries of the cap on damages. ${ }^{14}$ Likewise, some states prohibit informing the jury of the caps. For example, Maryland's statutory cap on noneconomic damages stipulates: "In a jury trial, the jury may not be informed of the limitation." ${ }^{" 15}$ Colorado limits noneconomic damages in all civil actions and requires that the cap "shall not be disclosed to a jury in any such action, but shall be imposed by the court before judgment." In In contrast, only two states explicitly allow the court to inform juries of a statutory limit. ${ }^{17}$

The purpose of these nondisclosure provisions is to prevent juries from being influenced by the presence of the statutory caps. One court noted that the purpose of the nondisclosure provision in the Civil Rights Act of 1991 is "to remove [the caps] altogether from the jury's consideration" and "to ensure that the jury does not feel pressure to structure or adjust verdicts "upward or downward' to account for the caps." ${ }^{\text {"18 }}$ These legislatures correctly worried that disclosure of the damage cap might unduly affect jury factfinding and distort damage awards.

\section{B. The Caselaw on Statutory Caps}

1. The constitutionality of statutory caps.

The enactment of these statutory caps on damages has been controversial. Plaintiffs have challenged the constitutionality of the caps under both the Seventh Amendment ${ }^{19}$ and analogous rights to a jury trial under state constitutions. ${ }^{20}$ These challenges to statutory caps are premised on the theory that damage caps

The jury shall not be advised of the limitation prescribed by this section. However, if a jury returns a verdict for punitive damages in excess of the maximum amount specified in this section, the judge shall reduce the award and enter judgment for such damages in the maximum amount provided by this section.

${ }^{14} 42$ USC $\$ 1981 \mathrm{a}(\mathrm{c})(2)$.

${ }^{15}$ Md Cts \& Jud Proc Code Ann § 11-108(d)(1).

${ }^{16}$ Colo Rev Stat Ann § 13-21-102.5(4) (West Supp 1998).

${ }^{17}$ Mass Ann Laws ch 231, $\$ 60 \mathrm{H}$ (Michie/Law Co-op Supp 1998) (requiring the court to instruct the jury of the cap in medical malpractice cases); W Va Code $\$ 55-7 \mathrm{~B}-8$ (permitting the court to disclose the cap to jurors in medical malpractice cases).

${ }^{18}$ Sasaki, 92 F3d at 236-37.

${ }^{19}$ US Const, Amend VII.

${ }^{20}$ See, for example, Md Decl Rts, Art 5; Ill Const 1970, Art I, § 13; Fla Const, Art I, $\$ 22$. Judicial treatment and analysis of the constitutionality of statutory caps is substantially similar under both the Seventh Amendment and state constitutional rights to a jury trial. 
usurp the factfinding role of the jury, guaranteed in the right to a jury trial, by overriding the jury's award when it exceeds the statutory maximum.

The Supreme Court has not decided whether statutory caps unconstitutionally infringe on the jury's authority. In Tull $v$ United States, ${ }^{21}$ however, the Court held that the Seventh Amendment required that a jury serve as factfinder in a government enforcement action under the Clean Water Act, ${ }^{22}$ but did not require that a jury determine the civil penalty in that case. ${ }^{23} \mathrm{Tull}$ held that "[t]he assessment of civil penalties . . . cannot be said to involve the 'substance of a common-law right to a trial by jury,' nor a 'fundamental element of a jury trial."24 Although Tull involved the assessment of a civil penalty, and not civil damages, the Court noted in dicta that "[n]othing in the [Seventh] Amendment's language suggests that the right to a jury trial extends to the remedy phase of a civil trial .... We have been presented with no evidence that the Framers meant to extend the right to a jury to the remedy phase of a civil trial."25 Thus, although Tull did not directly address compensatory damages, it established that the jury's authority does not necessarily include a determination of the remedy, even where the jury is the factfinder.

Many state courts, following Tull, have held that statutory caps do not violate the right to a jury trial guaranteed in their respective state constitutions, ${ }^{26}$ and federal courts have likewise upheld statutory caps under the Seventh Amendment. ${ }^{27}$ In the

${ }^{21} 481$ US 412 (1987).

${ }^{22} 33$ USC $\$ 1251$ et seq (1994).

${ }^{23} 481$ US at 426 .

${ }^{24}$ Id.

${ }^{25}$ Id at $426 \mathrm{n} 9$.

${ }^{26}$ See Adams v Children's Mercy Hospital, 832 SW2d 898, 907 (Mo 1992) (en banc); Murphy $v$ Edmonds, 325 Md 342, 601 A2d 102, 117-18 (1992); Wright $v$ Colleton County School District, 301 SC 282, 391 SE2d 564, 569-70 (1990); English v New England Medical Center Inc, 405 Mass 423, 541 NE2d 329, 331-32 (1989); Johnson v St Vincent Hospital, Inc, 273 Ind 373, 404 NE2d 585, 601-02 (1980). At least one court has upheld a statutory cap on different grounds. See Greist $v$ Phillips, 322 Or 281, 906 P2d 789, 797-98 (1995) (holding that the Oregon right to a jury trial incorporated the permissibility of statutory limitations on damages for wrongful death actions because such limits existed at the enactment of the Oregon constitution). Note that the Seventh Amendment does not apply to the states in civil trials. Minneapolis \& St. Louis RR v Bombolis, 241 US 211, 217-23 (1916).

${ }^{27}$ Following Etheridge $v$ Medical Center Hospitals, 237 Va 87, 376 SE2d 525 (1989), the Fourth Circuit held in Boyd v Bulala, 877 F2d 1191, 1196 (4th Cir 1989), that the Virginia cap on malpractice damages was constitutional under the Seventh Amendment. The court agreed with the Etheridge rationale and explained further: "If a legislature may completely abolish a cause of action without violating the right of trial by jury, we think it permissibly may limit damages recoverable for a cause of action as well." $877 \mathrm{~F} 2 \mathrm{~d}$ at 1196. A district court in Maryland agreed in Franklin v Mazda Motor Corp, 704 F Supp 1325, 
leading case for this position, Etheridge $v$ Medical Center Hospitals ${ }^{28}$ the Supreme Court of Virginia held that a statute limiting the damage recovery in malpractice actions did not violate the Virginia right of trial by jury. ${ }^{29}$ Consistent with Tull, the court acknowledged that "the jury's fact-finding function extends to the assessment of damages," but noted that "[o]nce the jury has ascertained the facts and assessed the damages, however, the constitutional mandate is satisfied." ${ }^{30}$ Although the jury's factfinding role includes an assessment of damages, the application of the remedy is a matter of law, not of fact. ${ }^{31}$

Some courts distinguish Tull, which involved a civil penalty, from a civil damages case and look to Dimick $v S$ Schiedt $t^{32}$ for authority instead. In declaring the practice of additur unconstitutional, the Supreme Court held that "both parties remain entitled ... to have a jury properly determine the question of liability and the extent of the injury by an assessment of damages. Both are

1330-34 (D Md 1989). The Third Circuit adopted a different approach in upholding a statutory damage cap in Davis v Omitowoju, 883 F2d 1155 (3d Cir 1989). Focusing upon the Seventh Amendment's prohibition against the reexamination of jury-tried facts, the court held that the judge's reduction of the jury's award was not "an act of reexamination of the jury verdict followed by an independent finding of a verdict for a different amount," but was instead an application of a law enacted by the legislature. Id at 1196. The court concluded that the Seventh Amendment "is primarily concerned with actions by the courts," rather than by legislatures. Id at $1162 \mathrm{n} 11$.

${ }^{23} 237 \mathrm{Va} 87,376$ SE2d 525 (1989).

20 $376 \mathrm{SE} 2 \mathrm{~d}$ at 529.

${ }^{3}$ Id.

${ }^{31}$ Id. For further discussion of the constitutionality of statutory caps under the right to a jury trial, see Murphy, 74 Tex L Rev 345 (cited in note 9) (arguing that statutory caps on damages are unconstitutional under the Seventh Amendment); Kenneth Owen O'Connor, Comment, Funeral for a Friend: Will the Seventh Amendment Succumb to a Federal Cap on Non-Economic Damages in Medical Malpractice Actions?, 4 Seton Hall Const L J 97 (1993) (analyzing potential federal tort reform and its constitutionality under the Seventh Amendment); James F. Tiu, Comment, Challenging Medical Malpractice Damage Award Caps on Seventh Amendment Grounds: Attacks in Search of a Rationale, 59 U Cin L Rev 213 (1990) (concluding that statutory caps are constitutional under the jury trial right); Janai M. Powell, Case Note, Challenging the Constitutionality of Noneconomic Damage Caps: Boyd v. Bulala and the Right to a Trial by Jury, 24 Willamette L Rev 821 (1988) (discussing various challenges to statutory caps under the right to a jury trial).

For analysis of the statutory caps under particular state constitutions, see Andrew D. Gowdown, Note, The Noneconomic Damages Cap of Ohio Revised Code Section 2744.05(C)(1): Legislative Usurpation of the Constitutional Right to Trial by Jury, $22 \mathrm{U}$ Dayton L Rev 283 (1997); James E. Magleby, The Constitutionality of Utah's Medical Malpractice Damages Cap Under the Utah Constitution, 21 J Contemp L 217 (1995); Stephen $\mathrm{K}$. Meyer, Comment, The California Statutory Cap on Noneconomic Damages in Medical Malpractice Claims: Implications on the Right to a Trial by Jury, 32 Santa Clara L Rev 1197 (1992); Marco de Sa e Silva, Comment, Constitutional Challenges to Washington's Limit on Noneconomic Damages in Cases of Personal Injury and Death, 63 Wash L Rev 653 (1988).

${ }_{32}^{293}$ US 474 (1935). 
questions of fact."33 Furthermore, the Court cautioned that "any seeming curtailment of the right to a jury trial should be scrutinized with the utmost care. ${ }^{\prime 34}$ The language in Tull seems in conflict with Dimick, declaring that determination of a remedy is not part of the jury factfinding function. Yet some courts have insisted on relying on Dimick and have distinguished Tull, despite its expansive language, as applying only to civil penalties rather than compensatory damages. These courts find statutory caps on damages unconstitutional..$^{35}$

The statutory caps have also faced constitutional challenges on grounds that they violate the plaintiff's rights to due process and equal protection. In addressing these issues, courts review the statute at issue to discern whether the deprivation of damages over the cap and the differential treatment of different types of tort victims bear a rational relationship to the public health or welfare. Some courts have decided that legislatures effectively responded to legitimate public concerns, have deferred to legislative judgments on policy, and have upheld the constitutionality of the caps. ${ }^{36}$ Other courts have concluded that the caps violate due process and equal protection rights because state legislatures had no reasonable basis for enacting damage caps in response to the problems of excessive awards and rising insurance rates. ${ }^{37}$ The

33 Id at 486.

36.

${ }^{35}$ See, for example, Knowles $v$ United States, 1996 SD 10, 544 NW2d 183, 186-87 (1996) (finding that damages are part of jury factfinding, citing Dimick); Sofie $v$ Fibreboard Corp, 771 P2d 711, 717-18 (Wash 1989) (limiting Tull to its context of a civil penalty in a regulatory enforcement case, and declining to extend Tull to a tort damages case). More recently, the Supreme Court weakened the precedential value of Tull by suggesting that the portion of the opinion relating to jury determination of damages was dicta. See Feltner $v$ Columbia Pictures Television, Inc, 523 US 340, 118 S Ct 1279, 1287-88 (1998) (holding that jury-determined damages in a copyright case preserved the "substance of the common-law right of trial by jury" because of historical evidence that juries, both in general and in copyright cases, set damages, and distinguishing Tull by noting that no such historical evidence had been presented in that case).

${ }^{36}$ See Davis, 883 F2d at $1158-59$ (finding a rational basis for a damage cap in the legislature's desire "to curb ... the high costs of malpractice insurance and thereby promote quality medical care"); Scholz $v$ Metropolitan Pathologists, 851 P2d 901, 906-07 (Colo 1993) (finding a rational basis for a damage cap in the legislature's effort to increase the availability of health care by stemming the increase in malpractice insurance premiums); Fein v Permanente Medical Group, 38 Cal 3d 137, 211 Cal Rptr 368, 695 P2d 665, 679-84 (1985) (holding that a damage cap was rationally related to a legitimate state interest in reducing the costs of medical malpractice litigation and, consequently, restraining the increase in malpractice insurance premiums). See also Butler $v$ Flint Goodrich Hospital of Dillard University, 607 S2d 517, 521 (La 1992) (holding that statutory cap does not violate equal protection and "[o]pen courts" provisions of Louisiana constitution).

3 See Knowles, 544 NW2d at 191 (holding that a damage cap violated the due process provision of the South Dakota constitution); Smith $v$ Schulte, 671 S2d 1334, 1344 (Ala 1995) (holding that a damage cap violated the equal protection and jury trial provisions of 
due process and equal protection violations, if they exist, are effectuated by the existence of the cap, not the prohibition on fully informing the jury. That is, the due process and equal protection claims, as alleged, challenge the legislature's authority to institute limits on recoverable damages, but do not implicate the nondisclosure of the cap.

\section{The constitutionality of nondisclosure of statutory caps.}

Although there has been a great deal of litigation regarding the constitutionality of the statutory caps themselves, to date only one court has decided whether a prohibition against disclosure to juries of statutory caps on damages is constitutional. In Murphy $v$ Edmonds ${ }^{38}$ the Court of Appeals of Maryland upheld a state cap on noneconomic damages, reasoning that legislative alteration of causes of action does not implicate the right to a jury trial under the Maryland constitution. ${ }^{39}$ In passing and without discussion, the court also upheld as constitutional the nondisclosure law, which prohibited the court from informing the jury about the applicable statutory cap. ${ }^{40}$

In other cases, courts have addressed nondisclosure laws while not explicitly passing on their constitutionality. In Best $v$ Taylor Machine Works, ${ }^{41}$ the Mlinois Supreme Court avoided consideration of the nondisclosure law by striking down the statutory cap itself. ${ }^{42}$ In Sasaki, the Fourth Circuit ordered a new trial based on its conclusion that the jury quite likely adjusted its award in response to impermissible disclosure of the damages cap

the Alabama constitution); Morris $v$ Savoy, 61 Ohio St 3d 684, 576 NE2d 765, 770-72 (1991) (holding that a damage cap violates the due process provision, but not the equal protection provision, of the Ohio constitution); Carson $v$ Maurer, $120 \mathrm{NH}$ 925, 424 A2d 825, 833-39 (1980) (holding, under a test more stringent than rational basis, that a damage cap violates the equal protection provision of the New Hampshire constitution). See also Best v Taylor Machine Works, 179 Il 2d 367, 689 NE2d 1057, 1078, 1096 (1997) (holding that statutory cap violates "special legislation" and "separation of powers" provisions of Illinois constitution); Lucas v United States, 757 SW2d 687, 690-92 (Tex 1988) (holding that statutory cap violates "access to the courts" provision of Texas constitution); Smith v Department of Insurance, 507 S2d 1080, 1087-89 (Fla 1987) (holding that statutory cap violates "access to the courts" provision of Florida constitution).

${ }_{38} 325 \mathrm{Md} 342,601$ A2d 102 (1992).

39 601 A2d at 116.

${ }^{40}$ Id at 116-17. With respect to the nondisclosure provision, the opinion stated only: "Neither the $\$ 350,000$ limit on recovery nor the provision that the jury shall not be informed of the limit, interferes with the jury's proper role and its ability to resolve the factual issues which are pertinent to the cause of action." Id at 117.

41 $179 \mathrm{Ml} 2 \mathrm{~d} 367,689 \mathrm{NE2d} 1057$ (1997).

${ }^{2} 689$ NE2d at 1104 (holding the cap unconstitutional as special legislation and a violation of separation of powers doctrine). 
in the Civil Rights Act of $1991 .^{43}$ The court, however, simply enforced the nondisclosure provision and did not address its constitutionality.

The First Circuit in Evans $v$ Avery ${ }^{44}$ concluded that it was not a reversible error for the district court to inform the jury of the applicable Massachusetts cap on damages for the plaintiff's state law claims where the Massachusetts statute was silent on disclosure. ${ }^{45}$ The court admitted that "[t]he wisdom of telling a jury about such a statutory limitation is debatable, and we do not recommend the practice." ${ }^{\text {"6 }}$ Yet the court noted that it "customarily cede[s] wide discretion to trial courts to fashion jury instructions," and upheld the lower court's decision to inform the jury despite its reservations. ${ }^{47}$ Similarly, in Pierce $v$ Central Maine Power $\mathrm{Co}^{48}$ the Maine Supreme Judicial Court held that the trial court did not err when it informed the jury of the statutory cap for wrongful death where the statute was silent on disclosure. ${ }^{49}$ The court presumed that the jury did not engage in misconduct and upheld the lower court's instruction..$^{50}$

Some scholars support a constitutional challenge to the nondisclosure of statutory caps based on the right to a jury trial. Professor Colleen Murphy has argued that even if a statutory cap on damages itself is constitutional, the jury is entitled to know and certainly not be misled about the applicable law and the legal consequences of its findings so that the jury can perform the factfinding role required under the right to a jury trial. ${ }^{51}$

43 F3d at 237-38.

4s 100 F3d 1033 (1st Cir 1996).

${ }^{45}$ Id at 1040. The Massachusetts statute requires disclosure of the statutory cap only in medical malpractice actions. Mass Ann Laws ch $231, \S 60 \mathrm{H}$.

${ }^{46} 100 \mathrm{~F} 3 \mathrm{~d}$ at 1040.

${ }^{47}$ Id.

4622 A2d 80 (Maine 1993).

49 Id at 83.

${ }^{50}$ Id (noting that there was no evidence that the jury ignored the court's instruction that "the jury could not shift damages in excess of the cap from one category to another").

${ }^{51}$ Murphy, 74 Tex L Rev at 401-02 (cited in note 9). Another commentator argues that nondisclosure is an impermissible intrusion on the jury's power to nullify the law because the jury is not informed of the statutory cap at which the jury's assessment of damages will be limited. Steven M. Fernandes, Comment, Jury Nullification and Tort Reform in California: Eviscerating the Power of the Civil Jury By Keeping Citizens Ignorant of the Law, 27 Sw U L Rev 99, 121 (1997). Fernandes, however, does not explain how disclosure alone would permit nullification of the damage cap given that the jury's role is limited to assessing damages and then leaving it to the court to cap those damages at the statutory limit. The jury cannot override the statutory limit, whether it knows about the cap or not, because the court ultimately applies the limit. 


\section{The Caselaw on Statutory Caps Supports a Judicial Policy of Nondisclosure}

Courts should adopt a policy of not disclosing statutory caps to juries. This policy follows logically from judicial reasoning upholding the constitutionality of caps: courts upholding caps have limited the jury's role to assessing damages but have not interpreted the jury trial right, under either the Seventh Amendment or state constitutions, as requiring courts to award that jury assessment to the plaintiff. These courts emphasize that the parties are entitled only to jury findings of fact. Because the right to jury factfinding does not include the right to receive the jury assessment of damages, it also does not include the right to inform the jury of the cap, particularly given clear legislative intent to separate the jury from the operation of the cap. The cap is a legal rule operating only after the jury has completed its constitutional function of factfinding. ${ }^{52}$ For example, in Etheridge, the Supreme Court of Virginia explained: "A trial court applies the remedy's limitation only after the jury has fulfilled its fact-finding function. Thus, [the cap] does not infringe upon the right to a jury trial because the [cap] does not apply until after a jury has completed its assigned function in the judicial process."

If the jury distorts its assessment of damages in order to arrive at its preferred outcome, this distortion would contradict the reasoning in Etheridge. Disclosure allows juries to "peek" at the legal effect of their findings and adjust their awards in a way that bears no proper relation to the evidence. If knowledge of the cap causes the jury to distort its award in this way, then the factfinding depends not only on the jury's evaluation of the case, but also on the jurors' personal preferences regarding the legal outcome of the case irrespective of the law. For this reason, courts in most cases generally have held as a matter of judicial policy that disclosure of the legal effect of jury findings-for example, the

\footnotetext{
${ }^{52}$ See Slocum v New York Life Ins Co, 228 US 364, 387 (1913) ("[I]t is the province of the jury to hear the evidence and by their verdict to settle the issues of fact."). The Seventh Amendment states only that "the right of trial by jury shall be preserved, and no fact tried by a jury, shall be otherwise re-examined." US Const, Amend VII. See also Edward Coke, 1 Commentary upon Littleton $\S 234$ (19th ed 1832) ("ad quaestionem facti non respondent judices (judges do not answer a question of fact) . . . ad quaestionem juris non respondent juratores (juries do not answer a question of law)"); Colleen P. Murphy, Integrating the Constitutional Authority of Civil and Criminal Juries, 61 Geo Wash L Rev 723, 745-54 (1993) (concluding "the constitutional history and structure . . . indicate that in civil cases, factfinding is within the jury's constitutional authority, whereas law declaration is not," but finding that "[r]egarding which institution should apply legal standards and rules in civil cases, the constitutional history and structure are less explicit").

376 SE2d at 529.
} 
consequences of conviction or the existence of treble damages-is improper. ${ }^{54}$

Striking nondisclosure laws, or permitting disclosure where the statute is silent, would contradict the Etheridge principle that jury factfinding should not be influenced by the statutory caps. ${ }^{55}$ If the jury is informed of the statutory cap, the jury's assessment of damages is no longer insulated from the cap. In those situations, the jury may not provide an unbiased and objective assessment of the facts. Disclosure introduces the possibility of jury misbehavior and result-oriented assessments unsupported by the evidence. In some cases, juries will likely attempt to evade the statutory limit for deserving plaintiffs. In other cases, knowledge of the cap is likely to influence jury awards as a result of an anchoring or measuring effect. ${ }^{56}$

A bar on disclosure helps to ensure that knowledge of the cap does not influence jury deliberation by dividing jury factfinding and the judge's translation of those findings into legal outcomes. Thus, even where the statute is silent on disclosure of a statutory cap on damages, courts should institute a nondisclosure rule.

\section{Disclosure OF STATUTORY CAPS LeAdS to DISTORTIONS OF JURY AWARDS}

This Part discusses the psychological effect on the jury of disclosure and explains how courts have addressed similar problems in other areas of law. If jurors know about an applicable statutory cap on damages, their determination of damages will not be based on a pure assessment of the facts. Indeed, psychological studies on jury behavior suggest that knowledge of a damage cap

\footnotetext{
${ }^{5 t}$ Disclosure of the legal effect of jury findings is a matter for judicial discretion unless a statute specifically mandates or prohibits disclosure. For example, the Fifth Circuit held that disclosure to the jury of the trebling of antitrust damages "would serve no useful function and its probable consequence would be harmful-an impermissible lowering of the amount of damages." Pollock \& Riley, Inc v Pearl Brewing Co, 498 F2d 1240, 1243 (5th Cir 1974). See also McGowan v Story, 70 Wis 2d 189, 234 NW2d 325, 329 (1975) ('Under our system of jurisprudence, the jury is the finder of fact and it has no function in determining how the law should be applied to the facts found."). Part II.B presents a full discussion of this issue with respect to the legal consequences of special verdict answers and criminal verdicts.

${ }^{65}$ A contrary view was expressed in Moore $v$ Mobile Infirmary Association, 592 So2d 156, 172-73 (Ala 1991) (Houston concurring). Judge Houston characterized the nondisclosure provision as the crux of the constitutional problem because the jury could not apply the law when the court was barred from disclosing the law: "I am of the opinion ... that a law specifically prohibiting a court from giving to a jury the law that a jury would traditionally apply to the facts and requiring the court to apply that law after a jury has completed its deliberations impinges upon the right to trial by jury." Id at 173 (Houston concurring).

${ }^{66}$ See Part II.A for further discussion of these issues.
} 
exerts an influence on the amount of an award unrelated to the jury's evaluation of the facts in a case. Citing the need to confine juries to making judgments on facts alone, courts have limited disclosure to juries of legal consequences in the analogous contexts of criminal law, nullification authority, and special verdicts. A similar policy of nondisclosure should be adopted with respect to statutory damage caps.

\section{A. Psychological Effects of Disclosure}

While statutory caps on damages are triggered in relatively few cases, ${ }^{57}$ disclosure of the caps likely would lead to significant distortions of jury awards. ${ }^{58}$ Such distortions would move jury awards away from the amount justified by the merits of the case. Disclosure, therefore, would contravene the legislative design of applying the cap only after the jury has made its award. This legislative design ensures that the jury will make a damage assessment based on findings of fact, uninfluenced by the statutory cap.

Nondisclosure was clearly intended for at least some statutory caps. For example, during congressional debate on the nondisclosure provision of the 1991 Civil Rights Act, one of the Act's chief proponents explained that "the bill specifically provides that the jury shall not be informed of the existence or amount of the caps on damage awards. Thus, no pressure, upward or downward, will be exerted on the amount of jury awards by the existence of the statutory limitations." ${ }^{\text {59 }}$ Legislators contemplated that knowledge of the cap might distort jury awards, and they deliberately inserted nondisclosure provisions to prevent such a result.

Although it is unclear exactly what effect knowledge of a statutory cap on damages will have on an individual jury, at least three possible distortions of jury awards might occur: evading the

\footnotetext{
${ }^{57}$ One national survey found that applicable statutory caps were triggered in just 7 percent of cases. David Baldus, John C. MacQueen, and George Woodworth, Improving Judicial Oversight of Jury Damages Assessments: A Proposal for the Comparative Additur/Remittitur Review of Awards for Nonpecuniary Harms and Punitive Damages, 80 Iowa $\mathrm{L}$ Rev 1109, 1122 (1995). In the average case, therefore, it is likely that the statutory limit would be set above what the average jury would have otherwise awarded.

${ }^{68}$ Verlin Hinsz and Kristin Indahl conducted two different studies, one where the disclosed limit was below the average award given by the control group (no knowledge of the cap) and one where the disclosed limit exceeded the average award given by the control group. Knowledge of the cap influenced the jury award in the direction of the limit for both conditions. Verlin B. Hinsz and Kristin E. Indahl, Assimilation to Anchors for Damage Awards in a Mock Civil Trial, $25 \mathrm{~J}$ App Soc Psych 991, 1005-06, 1013-15 (1995).

${ }^{59} 137$ Cong Rec S 15484 (Oct 30, 1991) (interpretive memorandum of Sen Danforth).
} 
cap, anchoring the award based on the cap, and scaling the damage award by reference to the cap.

First, juries may distort their award in order to evade the cap limit and give more money to a deserving plaintiff. In a meritorious case, the jury might be frustrated by the cap because it would limit the sum that the plaintiff receives to an amount below what the jury wants to award. Although the cap would cut off the jury's damage award at the maximum, the jury could circumvent the cap by awarding more than it otherwise would have for other claims not covered by a statutory cap. Consequently, if plaintiffs expect this result, they will push courts to disclose the applicable statutory cap in order to induce juries to evade the limit.

This result is not at all unlikely, as there is ample evidence that juries often focus on outcomes-for example, the adequacy of damage awards in a civil case, or the fairness of prison terms in the criminal context-rather than assess guilt or liability objectively on the evidence. Professors Reid Hastie, Steven Penrod, and Nancy Pennington concluded from their study of mock jury deliberations that some of the juries they observed were "verdictdriven," working backward in deliberation from the desired verdict to the evidence that supports it, in contrast to "evidencedriven" juries, who postponed verdict selection until after deliberation on the evidence. ${ }^{60}$ They found that "verdict-driven juries, in contrast to evidence-driven juries, are relatively hurried, cursory on testimony-law connections, less respectful of their own and others' persuasiveness and openmindedness, and less vigorous in discussion." ${ }^{\text {11 }}$ Another study found that juries in civil cases consider whether the defendant has liability insurance. ${ }^{62}$ Similarly, a study found that many juries consider whether the plaintiff has medical insurance to cover his or her injury expenses, although relatively few jurors report that a plaintiff's insurance coverage significantly affected their award..$^{63}$ Other studies have

${ }^{60}$ Reid Hastie, Steven D. Penrod, and Nancy Pennington, Inside the Jury 163-65 (Harvard 1983).

${ }^{61}$ Id at 165 . Of sixty-nine mock juries analyzed, nineteen were verdict-driven, twentyfour were evidence-driven, and twenty-six were mixed. Id at 164.

${ }^{62}$ Dale W. Broeder, The University of Chicago Jury Project, 38 Neb L Rev 744, 754 (1959). See also Harry Kalven, Jr., The Jury, the Law, and the Personal Injury Damage Award, 19 Ohio St L J 158, 171 (1958) (concluding that in doubtful cases, jurors are more likely to find against insured defendants, because "it is better to risk error against the insurance fund than against the injured plaintiff").

\& John Guinther, The Jury in America 98 (Facts on File 1988) (noting that jurors frequently discuss whether the parties have insurance but that jurors deny that this affects the amount of their award). 
discovered that jurors adjust damage awards in order to compensate plaintiffs for attorneys' fees. ${ }^{64}$ Despite instructions to the contrary, jurors in one case explained that they added about 40 percent to their computed award to compensate the plaintiff for attorneys' fees. ${ }^{65}$ Furthermore, mock jurors in criminal cases have been found to refuse conviction when they believe the penalty is too high, even though they believe the defendant is guilty of the crime. $^{66}$

One example of this outcome-based approach is Sasaki, in which the Fourth Circuit reversed a judgment because the jury appeared to have distorted its award to evade the statutory cap after the plaintiff's counsel improperly informed the jury of the cap in closing arguments. ${ }^{67}$ In that case, the same conduct that formed the basis for the plaintiff's federal claims also provided the basis for her state claims. ${ }^{68}$ After learning of the federal cap, the jury awarded $\$ 50,000$ for the federal claims-the maximum for noneconomic damages under the cap-but $\$ 150,000$ for noneconomic damages on the uncapped state claims based on the same conduct. The court concluded that the jury quite likely attempted to "award limited damages on the federal claims and 'more generous' damages on the state claims to avoid the federal cap. The jury here likely reacted in precisely the manner that Congress specifically feared. ${ }^{\prime \prime 9}$ A jury behaved similarly in Rosen-

${ }^{64}$ Allan Raitz, et al, Determining Damages: The Influence of Expert Testimony on Jurors' Decision Making, 14 L \& Hum Beh 385, 392-93 (1990) (one-quarter of mock jurors said they considered attorneys' fees); Fred L. Strodtbeck, Social Process, the Law, and Jury Functioning, in William M. Evan, ed, Law and Sociology 144, 154-58 (Free Press of Glencoe 1962) (presenting evidence from mock jury deliberations showing that jurors inflate awards to account for attorneys' fees).

${ }^{65}$ Molly Selvin and Larry Picus, The Debate over Jury Performance: Observations from a Recent Asbestos Case 38-39, 41 (Rand 1987).

${ }^{66}$ Bernard Grofman, The Effect of Restricted and Unrestricted Verdict Option on Juror Choice, 14 Soc Sci Rsch 195, 203 (1985); Harry Kalven, Jr. and Hans Zeisel, The American Jury 306-12 (Little, Brown 1966). Although Grofman's is the only study that separated the judgment of guilt from demand for higher standard of proof, see also Norbert L. Kerr, Severity of Prescribed Penalty and Mock Jurors' Verdicts, $36 \mathrm{~J}$ Personality \& Soc Psych 1431, 1432-34 (1978) (reviewing evidence of inverse relation between punishment severity and likelihood of conviction); William C. McComas and Mark E. Noll, Effects of Seriousness of Charge and Punishment Severity on the Judgments of Simulated Jurors, 24 Psych Rec 545 (1974) (separating the effect of seriousness of charge from effect of length of sentence); Neil Vidmar, Effects of Decision Alternatives on the Verdicts and Social Perceptions of Simulated Jurors, 22 J Personality \& Soc Psych 211, 214-16 (1972) (finding that when a guilty verdict has more severe consequences, mock jurors are more likely to return a not guilty verdict).

${ }^{67} 92$ F3d at 237.

${ }^{\infty}$ Id.

${ }^{\infty}$ Id. 
thal $v$ Kolars. ${ }^{70}$ After returning a verdict, the jury was surprised to learn that the plaintiff would not receive the full award under comparative negligence. The court decided to reinstruct the jury on comparative negligence law. After fifteen minutes of further deliberation, the jury returned an increased damage award. ${ }^{71}$

A second effect of disclosure of a statutory cap is that juries might "anchor" their deliberations to that amount. Empirical research has discovered that people tend to make estimates by starting with an initial value and then adjusting upward or downward from there. Since these adjustments are usually small, the initial starting point significantly influences the ultimate figure. ${ }^{72}$ Further empirical work has found this occurs in the jury setting as well. ${ }^{73}$ For example, in one mock jury study, the median award was $\$ 37,500$ when no cap was mentioned. However, when the jury was told that the cap was $\$ 2$ million, the median award was $\$ 775,000 .^{74}$ This research indicates that jury awards are pushed toward the damage limit because juries tend to begin their calculation of damages with that figure as a starting point. That is, juries that know about a limit on damages tend to make awards that are significantly closer to that figure than juries that do not know about the limit.

For example, juries already anchor on the plaintiff's damage request, the "ad damnum," as a starting point for deliberation on damages. ${ }^{75}$ In one experimental study, mock jurors delivered

70 304 Minn 378, 231 NW2d 285 (1975).

${ }^{71} 231$ NW2d at 288.

${ }^{72}$ This phenomenon is called "anchoring." See Amos Tversky and Daniel Kahneman, Judgment Under Uncertainty: Heuristics and Biases, 185 Science 1124, 1128-30 (1974). See also Robin M. Hogarth and Hillel J. Einhorn, Order Effects in Belief Updating: The Belief-Adjustment Model, 24 Cognitive Psych 1 (1992) (refining the anchoring model); Robert S. Wyer, Jr. and Thomas K. Srull, Memory and Cognition in its Social Context 32528 (Erlbaum 1989) (discussing additional research investigating the anchoring effect).

${ }^{73}$ See Hinsz and Indahl, $25 \mathrm{~J}$ App Soc Psych at 1016 (cited in note 58) (finding that the caps serve as anchors in mock juries' damage awards); Michael J. Saks, et al, Reducing Variability in Civil Jury Awards, 21 L \& Hum Beh 243, 253-54 (1997). There is some evidence that anchoring and adjustment occur in determining liability as well. See Robert MacCoun, Inside the Black Box: What Empirical Research Tells Us about Decisionmaking by Civil Juries, in Robert E. Litan, ed, Verdict: Assessing the Civil Jury System 137, 15253 (Brookings 1993).

"3insz and Indahl, $25 \mathrm{~J}$ App Soc Psych at 1006 (cited in note 58).

${ }^{25}$ See Broeder, 38 Neb L Rev at 756-60 (cited in note 62) (finding this effect through jury interviews in six of seven cases studied). See also Edith Greene, On Juries and Damage Awards: The Process of Decisionmaking, $52 \mathrm{~L}$ \& Contemp Probs 225, 234 (1989) (citing other studies showing that juries "anchor" to various suggestions of damage awards). What happens when the jury is presented both with a statutory limit and the ad damnum? It is likely that the jury will be much more influenced by the statutory cap, which carries the stamp of government deliberation, than the ad damnum, which is less credible because of the self-interest of the plaintiff. This conclusion is supported by the findings of 
damage awards proportionate to the ad damnum. ${ }^{76}$ When the plaintiff requested "substantial compensation" with no dollar figure specified, the average award was $\$ 74,600 .{ }^{77}$ However, when juries were presented with damage requests of $\$ 10,000, \$ 75,000$, and $\$ 150,000$, the average awards were $\$ 18,000, \$ 62,800$, and $\$ 101,400$ respectively. ${ }^{78}$ Similarly, another study found in two different mock cases that each of four increases in the ad damnum brought a corresponding increase in the average award. ${ }^{79}$

Thus, the jury appears to use the plaintiff's request for damages as a starting point for its discussion and deliberation; consequently, it ultimately awards damages in proportion to the plaintiff's request. These studies suggest that juries will similarly anchor on a disclosed statutory maximum figure. Because of the anchoring effect, juries that would have awarded significantly less than the cap figure if the cap were not disclosed might award damages closer to the cap upon disclosure.

The third effect of disclosure of statutory caps is the scaling effect. Research suggests that people tend to use the range of proffered response alternatives as a frame of reference for estimation tasks. ${ }^{80}$ While jurors should apply their own judgment in quantifying the plaintiff's damages, jurors may perceive the statutory limit to be a scale along which damages should be de-

Professor Raitz and his colleagues. See Raitz, et al, 14 L \& Hum Beh at 394 (cited in note 64) (finding that jurors consider the credibility of competing anchors and then are influenced primarily by only one of them).

${ }^{76}$ J.J. Zuehl, The Ad Damnum, Jury Instructions, and Personal Injury Damage Awards 53 table 4 (University of Chicago Dept of Sociology, Aug 4, 1982) (unpublished manuscript on file with $\mathrm{U}$ Chi $\mathrm{L}$ Rev) (concluding that in mock trials, jury awards were responsive to the amount of the plaintiffs ad damnum), described in MacCoun, Inside the Black Box at 157 (cited in note 73).

7 Zuehl, The Ad Damnum at 53 table 4 (cited in note 76).

73 Id.

${ }^{79}$ John Malouff and Nicola S. Schutte, Shaping Juror Attitudes: Effects of Requesting Different Damage Amounts in Personal Injury Trials, 129 J Soc Psych 491, 495 (1989) (In two separate cases, each $\$ 200,000$ increase in the ad damnum led to roughly an additional $\$ 100,000$ in damages.).

${ }^{80}$ See Norbert Schwarz, et al, Response Scales as Frames of Reference: The Impact of Frequency Range on Diagnostic Judgements, 5 App Cognitive Psych 37, 47 (1991); Norbert Schwarz, et al, Response Scales: Effects of Category Range on Reported Behavior and Comparative Judgments, 49 Pub Op Q 388, 394 (1985). See also George D. Gaskell, Colm A. O'Muircheartaigh, and Daniel B. Wright, Survey Questions about the Frequency of Vaguely Defined Events: The Effects of Response Alternatives, 58 Pub Op Q 241, 250-52 (1994).

The scale of responses given influences people's estimations to a greater degree when the estimation task presented is more difficult. Therefore, the scaling effect will be stronger in cases that demand more complicated damage estimations. See Herbert Bless, et al, Asking Difficult Questions: Task Complexity Increases the Impact of Response Alternatives, 22 Euro J Soc Psych 309, 311-12 (1992). 
termined, rather than as an uppermost limit on damages. ${ }^{81}$ They might consider the cap amount to represent a government predetermination of the amount that should be awarded in the worst injury scenario with lesser harms scaled down proportionately from that standard..$^{82}$ The jurors would thus "scale" their assessment by calibrating it against the cap figure. For example, a jury might assume that a $\$ 50,000$ cap means that a case in which the plaintiff suffered moderate harm merits an award of half the maximum, or $\$ 25,000$. Had the jury not known of the cap, however, the jury may have awarded much more than $\$ 25,000-$ or even more than the cap-based on its findings of fact and the evidence presented at trial. If jurors take this improper signal from disclosure of the cap, knowledge of the cap would distort the jury's award from what it otherwise would have been.

It is unclear whether jury assessments of damages would be pushed upward or downward as a result of the scaling effect, but either would constitute a distortion in the jury award unrelated to the merits of the case. If the plaintiff thought the effect would push damage awards upward, she would press for disclosure; if, conversely, the defendant thought the effect would push damage awards downward, he would have an incentive to ask the court to disclose the statutory cap.

Although the three different effects of jury bias as a result of the cap point in different directions-the evasion attempt and anchoring effect seem to favor plaintiffs, and the scaling effect favors either plaintiffs or defendants-they do not offset each other. That is, these effects do not "cancel out," because they occur in different circumstances. The anchoring effect pulls the damage assessment closer to the cap figure in every case. The evasion attempt occurs only when the jury rejects the appropriateness of a statutory limit for the plaintiff's injury, whereas the scaling effect occurs when the jury accepts the legitimacy of a statutory limit and uses it to gauge its own damage assessment. The evasion at-

\footnotetext{
${ }^{81}$ For example, in Peot v Ferraro, 83 Wis 2d 727, 266 NW2d 586 (1978), the Supreme Court of Wisconsin noted that the "usual arguments against allowing the jury to be told the dollar limitation are that the jury may give this dollar figure too great weight ... and that the jury is likely to believe that the amount stated in the instruction measures rather than limits the permissible recovery." Id at 595. The court opined that this problem might be addressed by a jury instruction that the statutory figure is not a measure of damage, but a limit. Id at 595-96. However, it is unclear empirically whether this would cure the distortion, whereas nondisclosure would prevent it completely.

\$2 This type of scaling effect occurs with respect to the ad damnum as well. For example, the University of Chicago Jury Project concluded that juries often guess that lawyers ask for "twice what they expect" based on the evidence and grant damages with that judgment in mind. Broeder, $38 \mathrm{Neb} \mathrm{L}$ Rev at 757-59 (cited in note 62).
} 
tempt and scaling effect will affect the ultimate damage award only when the jury, without disclosure, would have awarded more than the cap; the anchoring effect and scaling effect will affect the ultimate damage award only when the jury would have awarded less than the cap because any assessment above the cap would be cut off at the limit. Thus, the different effects will rarely offset each other in the same case; instead, they present opportunities for distortion of awards in different types of cases.

One could argue that jurors might know about the caps before they serve, and therefore nondisclosure would be ineffective. ${ }^{83}$ Whether nondisclosure would be more confusing to juries than disclosure depends in part on an empirical question about the magnitude of juror bias due to speculation about ultimate outcomes and the existence of statutory caps. When a jury "guesses" that the statutory cap will apply to its damage award and speculates that the cap is set at a certain figure, jury speculation already biases deliberation significantly; in this case informing the jury about the cap is likely to have a beneficial effect because then the jury at least would be certain of the statutory limit, eliminating the possibility that the jurors would incorrectly guess the limit. Today, however, most citizens probably know little if anything about the caps. Undisclosed statutory caps operate outside of the awareness of most jurors; jurors likely assume that the plaintiff will receive the award of damages that they assess. Thus, unlike special verdicts, ${ }^{84}$ caps do not invite speculation regarding the end results. This may change, however, as statutory caps become increasingly common and enter the popular consciousness. In most cases today, nondisclosure would suffice to insulate jurors from knowledge of the caps. For now, based on the empirical research on the psychology of juries, courts should adopt a policy of nondisclosure because informing the jury of a statutory cap threatens to distort jury assessments of damages.

${ }^{3}$ Diamond and Casper discuss the problem of "wild-card" jurors who happen to know a nondisclosed rule and reveal the rule to fellow jurors. Worse, a juror actually might be misinformed about the rule and incorrectly tell fellow jurors about a rule that will be in effect. Shari Seidman Diamond and Jonathan D. Casper, Blindfolding the Jury to Verdict Consequences: Damages, Experts, and the Civil Jury, 26 L \& Society Rev 513, 538-39 (1992). See also William W. Schwarzer, Reforming Jury Trials, 1990 U Chi Legal F 119, 133-34 (arguing that jurors' misinformation results in unfairness and prejudice).

s See notes 103-05 and accompanying text for a discussion of courts' general policy of not disclosing to the jury the legal consequences of the special verdict form. 


\section{B. Judicial Policy on Disclosure in Other Areas of Law}

This Part examines courts' policies of nondisclosure in other contexts and concludes that these policies support a policy of nondisclosure of statutory caps on damages. Traditionally, courts have adopted rules of nondisclosure in other contexts based on the same policies that apply to statutory caps. Courts have discussed the strong public policy rationale behind nondisclosure and the division of functions between jury and judge. Many of the cases do not involve statutes prohibiting or mandating jury disclosure, but courts have elected a judicial policy of nondisclosure in the absence of legislative instruction. Although these cases arise in a wide variety of areas of law, the rationale for the nondisclosure rule discussed in these cases-that jury findings ought not be influenced by consideration of their legal consequencesapplies with equal force to a judicial policy of nondisclosure in the context of statutory damage caps. ${ }^{85}$

For example, nearly all jurisdictions hold that courts should not inform the jury of the consequences of conviction in a criminal case. ${ }^{86}$ The Supreme Court has held that, if asked about sentencing consequences, the court should instruct the jury that it "ha[s] no sentencing function and should reach its verdict without regard to what sentence might be imposed." ${ }^{87}$ A typical application of this rule is Commonwealth $v$ Ferreira ${ }^{88}$ in which a Massachusetts court reversed a conviction based on the lower court's disclo-

${ }^{85}$ Although legislatures did not expressly prohibit disclosure with respect to some statutory caps, this legislative silence should not be interpreted as legislative intent to permit disclosure. Instead, it is likely that the legislators simply took no position on disclosure and left it to the courts, as legislatures typically do with respect to disclosure of the legal consequences of jury findings. In at least two states, legislatures considered the issue and decided in favor of a policy of disclosure by expressly permitting disclosure in statutes. See Mass Ann Laws ch 231, $\S 60 \mathrm{H}$ (requiring disclosure of a cap in medical malpractice cases); W Va Code $§ 55-7 \mathrm{~B}-8$ (permitting disclosure of a cap in medical malpractice cases).

${ }^{86}$ See Sanford H. Kadish and Stephen J. Schulhofer, Criminal Law and Its Processes: Cases and Materials 70 (Aspen 6th ed 1995). See also United States $v$ Davidson, 367 F2d 60, 63-64 (6th Cir 1966) (holding that instruction informing jury of its ability to recommend leniency was prejudicial error, because it allowed the jury to consider the punishment that the defendants would receive); McClanahan $v$ United States, 292 F2d 630, 634 (5th Cir 1961) (declining to find error in a jury instruction explaining that the jury would not be concerned with punishment, but only with the question of guilt or innocence). See also Kristen K. Sauer, Note, Informed Conviction: Instructing the Jury About Mandatory Sentencing Consequences, 95 Colum L Rev 1232, 1242-43 (1995) (noting that general rule "has never been considered mandatory"); Milton Heumann and Lance Cassak, Not-SoBlissful Ignorance: Informing Jurors About Punishment in Mandatory Sentencing Cases, 20 Am Crim L Rev 343, 358-61 (1983) (explaining the "general rule" that jurors are not to be informed of the possible punishment).

${ }^{87}$ Rogers $v$ United States, 422 US 35, 40 (1975).

373 Mass 116, 364 NE2d 1264 (1977). 
sure to the jury of the sentencing and parole consequences of the charges. ${ }^{89}$ The court noted that it "ha[s] long held that the sentencing consequences of a verdict may not be submitted to the jury because the jury's function is to reach a verdict based solely on the evidence presented to them .... [T]he jury's function is solely one of fact finding." $" 90$

Courts mandating nondisclosure in these circumstances have argued that the jury ought to focus on the evidence presented and serve as an impartial finder of fact. Introduction of sentencing information might unduly influence the jury's findings and distract the jury from considering the factual issues at hand. The court in Commonwealth $v$ Mutina ${ }^{91}$ summarized this view as follows:

The principal argument for rejecting the practice of instructing juries as to the legal consequences of their verdicts in criminal cases seems to lie in the conviction that in reaching their verdicts, jurors should be shielded from extraneous influences and should arrive at their verdicts only on a dispassionate consideration of the relevant and credible evidence ... . To inform jurors of the consequences of their verdicts is apparently seen ... as inviting result-oriented verdicts and possible deviation from the basic issues of a defendant's guilt or innocence. ${ }^{92}$

This rule of nondisclosure also applies to the sentencing consequences of the verdict of not guilty by reason of insanity. In Shannon $v$ United States ${ }^{93}$ the Supreme Court reasserted the division of labor between judge and jury: "The jury's function is to find the facts and to decide whether, on those facts, the defendant is guilty ... . The judge, by contrast, imposes sentence . . . after the jury has arrived at a guilty verdict. Information regarding the consequences of a verdict is therefore irrelevant to the jury's

364 NE2d at 1272.

${ }^{\circ 0}$ Id at 1270. See also United States $v$ Broxton, 926 F2d 1180, 1183 (DC Cir 1991) ("[T]he jury is not to consider the potential punishment which could result from a conviction."); People $v$ Cipollone, 106 AD2d 458, 482 NYS2d 552, 553 (NY App Div 1984) (“It is axiomatic that punishment is within the sole province of the court and may not be considered by the jury, either out of sympathy for the defendant or for retribution purposes against the defendant."); People $v$ Holt, 37 Cal 3d 436, 690 P2d 1207, 1219 (1984) (“A defendant's possible punishment is not a proper matter for jury consideration.").

${ }^{91} 366$ Mass 810, 323 NE2d 294 (1975). See also the research cited in note 66 describing the influence of knowledge of sentences on juror decisions.

${ }^{92} 323 \mathrm{NE} 2 \mathrm{~d}$ at 298. After explaining the rationale for a policy of nondisclosure, the Mutina court held that juries ought to be informed about the consequences of a verdict of not guilty by reason of insanity. Id at 301.

${ }^{33} 512$ US 573 (1994). 
task." ${ }^{94}$ Analyzing the Insanity Defense Reform Act of $1984,{ }^{95}$ which was silent on the issue of sentencing disclosure,$^{96}$ the Court refused to depart from the well-established common law principle of nondisclosure "without more explicit guidance from Congress." ${ }^{\prime 97}$

Similarly, almost all courts refuse to give instructions informing juries about their nullification authority. ${ }^{98}$ Courts reason that instructing the jury on nullification would encourage the jury to disregard the court's instructions and the factual issues presented in the case. Although the right of jury nullification is well-established ${ }^{99}$ courts fear that an explicit instruction on nullification risks jury rulemaking unbounded by the law: "The practicalities of men, machinery and rules point up the danger of articulating discretion to depart from a rule, that the breach will be more often and casually invoked." ${ }^{100}$ In fact, a nullification in-

Id at 579.

${ }^{55} 18$ USC $\S \S 17,4241-47$ (1994).

${ }^{96} 512$ US at 580 .

${ }^{97}$ Id at 587. See also United States $v$ Fisher, 10 F3d 115, 123 (3d Cir 1993) (holding that district court did not abuse its discretion by withholding instruction on the consequences of a not guilty by reason of insanity verdict); United States $v$ Thigpen, 4 F3d 1573, 1578 (11th $\mathrm{Cir} 1993$ ) ("[T]he general rule against informing jurors of the consequences of a verdict governs [insanity] cases."). See also Rick L. Sorensen, Note, Shannon v. United States: Supreme Court Determines Whether Federal Courts Should Instruct Juries on the Consequences of a Not Guilty by Reason of Insanity Verdict, 21 J Contemp L 365 (1995) (setting forth caselaw and the general rule of nondisclosure).

${ }^{*}$ See, for example, United States v Avery, 717 F2d 1020, 1027 (6th Cir 1983) (holding that the argument that the court should have instructed the jury on its nullification power "is completely without merit"); United States v Dougherty, 473 F2d 1113, 1130-37 (DC Cir 1972) (providing an extensive history of the rule against disclosure of the jury's power to nullify the law).

* cThere has evolved in the Anglo-American system an undoubted jury prerogative-infact, derived from its power to bring in a general verdict of not guilty in a criminal case, that is not reversible by the court... The pages of history shine on instances of the jury's exercise of its prerogative to disregard uncontradicted evidence and instructions of the judge." Dougherty, 473 F2d at 1130. For commentary arguing that juries should be informed of their right to nullify, see David C. Brody, Sparf and Dougherty Revisited: Why the Court Should Instruct the Jury of its Nullification Right, 33 Am Crim L Rev 89 (1995); Jeffrey Abramson, We, the Jury: The Jury System and the Ideal of Democracy 57-95 (Basic Books 1994); Alan W. Scheflin, Jury Nullification: The Right to Say No, 45 S Cal L Rev 168, 196-226 (1972); Robert J. Stolt, Note, Jury Nullification: The Forgotten Right, 7 New Eng L Rev 105, 116-21 (1971).

${ }^{100}$ Dougherty, 473 F2d at 1135. See also Sparf v United States, 156 US 51, 90-99 (1895) (acknowledging jury nullification but affirming the principle that judges declare the law and juries must apply it). For commentary advising against disclosure, see Jack B. Weinstein, Considering Jury "Nullification": When May and Should a Jury Reject the Law to Do Justice, 30 Am Crim L Rev 239 (1993); Eleanor Tavris, The Law of an Unwritten Law: A Common Sense View of Jury Nullification, 11 W St U L Rev 97 (1983); Gary J. Simson, Jury Nullification in the American System: A Skeptical View, 54 Tex L Rev 488, 512-25 (1976). 
struction is clear reversible error. ${ }^{101}$ Furthermore, it is proper for a court not only to refuse to disclose the nullification option, but also deliberately to misinform the jury that "[t]here is no such thing as valid jury nullification."102

In addition, most courts do not disclose to the jury the legal outcomes that result from special verdict findings. ${ }^{103}$ These courts agree that nondisclosure reduces the temptation for juries to focus on ultimate outcomes and limits the chance of result-oriented findings. The Seventh Circuit has explained that special verdicts are specifically designed to "concentrate the jury's attention exclusively upon the fact questions put to them. Comment on the legal effects of the answers could in an appropriate case have a prejudicial effect of clouding this purpose."104 Likewise, another court concluded that it is "improper for a trial judge to instruct the jury as to the law or the legal effect of their factual findings. 105

Nondisclosure prevents jury factfinding from becoming driven by results rather than objective deliberation based on the evidence. The jury's function of factfinding is foremost, and the

\footnotetext{
${ }^{101}$ State v McClanahan, 212 Kan 208, 510 P2d 153, 158-60 (1973).

${ }^{102}$ United States $v$ Krzyske, 836 F2d 1013, 1021 (6th Cir 1988). See also People v Fernandez, 26 Cal App 4th 710, 31 Cal Rptr 2d 677, 680 (1994) (finding no error in trial court's refusal of jury's request for conviction on a lesser charge).

${ }^{103}$ The traditional majority rule is the "Wisconsin Rule" prohibiting disclosure. See, for example, Thedorf $v$ Lipsey, 237 F2d 190, 193 (7th Cir 1956) ("[T] he jury are [sic] supposed to find and report all the material facts without any instructions as to what will be the legal result of their finding."), quoting Ward v Cochran, 71 F 127, 134 (8th Cir 1895); Carvalho v Raybestos-Manhattan, Inc, 794 F2d 454, 457 n 2 (9th Cir 1986) ("[T]he district court did not abuse its discretion in refusing to inform the jury of the consequences of the answers to the interrogatories."); Lozado v City of Chicago, 279 Ill App 3d 285, 664 NE2d 333, 335 (1996) ("It is reversible error . . . to discuss the legal effect of the [special verdict]."). Recently courts have been adopting a disclosure rule in comparative negligence cases. See, for example, Roman v Mitchell, 82 NJ 336, 413 A2d 322, 327 (1980) (holding that a jury should be informed of the comparative negligence rule "so that its deliberations on percentages of negligence will not be had in a vacuum, or possibly based on a mistaken notion of how the statue operates"); Seppi $v$ Betty, 99 Idaho 186, 579 P2d 683, 690-92 (1978) (holding that a court could inform the jury of the effect of its judgment and noting that a comparative negligence law barring recovery if the plaintiff's negligence is 50 percent or more "poses a trap for the uninformed jury," since uncertain jurors will gravitate to a fifty-fifty allocation of liability). See also Mark S. Brodin, Accuracy, Efficiency, and Accountability in the Litigation Process-The Case for the Fact Verdict, $59 \mathrm{U}$ Cin L Rev 15, 51-84 (1990) (discussing the disclosure issue and the history of special verdicts); Martin A. Kotler, Reappraising the Jury's Role as Finder of Fact, 20 Ga L Rev 123, 123-24 (1985) (noting widespread acceptance of nondisclosure but describing a trend toward disclosure); Stuart F. Schaffer, Comment, Informing the Jury of the Legal Effect of Special Verdict Answers in Comparative Negligence Actions, 1981 Duke L J 824, 830-33 (discussing the unanimous use of the "Wisconsin Rule" until the 1970s).

${ }^{104}$ Gullett v St. Paul Fire \& Marine Insurance Co, 446 F2d 1100, 1105 (7th Cir 1971).

${ }^{105}$ Feder $v$ Bankers National Life Insurance Co, 100 NJ Super 458, 242 A2d 632, 635 (Super Ct App Div 1968).
} 
jury's role of interposing lay judgment into the harsh application of the law is subordinate. Under this framework, disclosure of statutory caps is unacceptable to the degree that it threatens the integrity of jury factfinding by introducing the distortions discussed in Part II.A.

Some argue, however, that juries serve an important role in tempering the harsh consequences of impartial application of the law and serve justice by mitigating the effect of the cap for deserving plaintiffs for whom the statutory maximum is unjustly insufficient. They claim that disclosure of the cap offers flexibility by reinjecting jury sensibilities in those cases where the cap operates as an injustice. ${ }^{106}$ In this view, informing the jury actually minimizes prejudice and permits the jury to consider adjusting its factual findings in light of their realistic consequences.

This theory is not compelling. Even courts that espouse this view must agree that the primary role of the jury is factfinding. ${ }^{107}$ To the degree that disclosure of the caps undermines the integrity of jury findings, disclosure is unacceptable. Indeed, allowing juries to mitigate the effect of the cap frustrates the legislative intent behind statutory caps-limiting excessive jury awards-and produces findings based on end results rather than objective consideration of the facts. The statutory cap enacted through the legislative process carries a democratic pedigree that courts should not undermine by allowing disclosure of the caps to the jury.

${ }^{106}$ See David N. Dorfman and Chris K. Ijjima, Fictions, Fault, and Forgiveness: Jury Nullification in a New Context, 28 U Mich J L Reform 861, 889-901 (1995) (arguing that knowledge of nullification authority will restore respect among racial minorities for a criminal justice system they perceive to be biased); Sauer, Note, 95 Colum L Rev at 125460 (cited in note 86) (arguing that jury nullification checks the enforcement of outdated, overinclusive, and overly harsh laws); David E. Pierce, Note, Informing the Jury of the Legal Effect of its Answers to Special Verdict Questions Under Kansas Comparative Negligence Law-A Reply to the Masses; A Case for the Minority View, 16 Washburn L J 114, 132-33 (1976) (noting that informing jurors of the legal effect of their response to special verdicts allowed them to mitigate harsh outcomes under contributory negligence, but concluding that this function is not necessary under comparative negligence). Note, however, that the jury's role of tempering harsh consequences of the law applies more weakly in the civil than in the criminal context. See Sauer, Note, 95 Colum L Rev at 1251 (observing that in the civil context, a judge may set aside a jury verdict that is against the weight of the evidence and noting that jury nullification exists only in the criminal context because it is a check on government power); Kotler, $20 \mathrm{Ga} \mathrm{L}$ Rev at 160-61 (cited in note 103) ("[T]he traditional justification for the existence of the power to nullify makes little sense in the context of a civil lawsuit.").

${ }^{107}$ See, for example, Shannon, 512 US at 579 ("The jury's function is to find the facts."); Pope v United States, 298 F2d 507, 508 (5th Cir 1962) ("Generally speaking, jurors decide the facts."). 
While questionable in any context, this notion of jury as mitigator of law is particularly inapt with respect to statutory caps. Statutory caps reflect legislative conclusions that juries are ill-prepared to make the inexact estimations inherent in the assessment of noneconomic damages. ${ }^{108}$ As affirmed by many courts in reviewing the constitutionality of the caps under the due process and equal protection guarantees, the enactment of these caps was a direct democratic response to concerns regarding excessive jury awards for noneconomic harm and the resulting social harm. ${ }^{109}$ The caps represent a legislative determination that noneconomic damages should be bounded by a reasonable maximum amount rather than left to the unfettered discretion of the jury. ${ }^{110}$ Disclosure invites juries to attempt to circumvent statutory caps. Although disclosure may allow juries to mitigate the effect of the cap, it would directly frustrate the democratic process that enacted the cap. ${ }^{111}$

In addition, the statutory cap only limits the plaintiffs award to a figure determined by the legislature to be the maximum reasonable amount justified for such damages. Although the plaintiff might consider the cap figure to be a harsh outcome of law, the legislature set the cap based on evidence about those classes of noneconomic damage. This is not a harsh outcome of law that requires the mitigating intervention of juries.

\footnotetext{
${ }^{109}$ Empirical research, for example, shows that juries make highly inconsistent awards for noneconomic damages. See Cass R. Sunstein, Daniel Kahneman, and David Schkade, Assessing Punitive Damages (With Notes on Cognition and Valuation in Law), 107 Yale L J 2071, 2100-03 (1998) (demonstrating low correlation between outrageousness of defendant's conduct and size of punitive damage award); Baldus, MacQueen, and Woodworth, 80 Iowa L Rev at 1115 (cited in note 57) ("The problem of outlying, or inconsistent, damages awards is inherent in a system that allocates responsibility ... to inexperienced jurors."). Sunstein, Kahneman, and Schkade cite a study analyzing data from eleven states over several years that found that median punitive damage verdicts varied from less than $\$ 10,000$ in some areas to $\$ 204,000$ in San Diego. Stephen Daniels and Joanne Nartin, Myth and Reality in Punitive Damages, 75 Minn L Rev 1, 42 table VI (1990).

${ }^{109}$ See text accompanying notes $36-37$.

${ }^{110}$ See Franklin v Mazda Motor Corp, 704 F Supp 1325, 1333 (D Md 1989) ("The Maryland cap on noneconomic damages represents a policy judgment by the legislature that pain and suffering will be compensable in a range between zero and $\$ 350,000$. This type of policy judgment is not foreign to the legislature.").

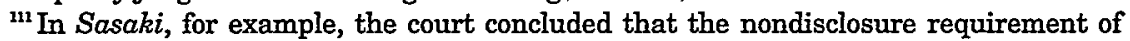
the 1991 Civil Rights Act prevented attorneys, as well as the court, from disclosing the damage cap, noting: "The statute's explicit preclusion of the court from mentioning the caps was plainly designed to remove them altogether from the jury's consideration." 92 F3d at 236.
} 


\section{CONCLUSTON}

Statutory caps on awards for noneconomic damages are increasingly prevalent. Plaintiffs are likely to begin trying to evade these caps by disclosing them to the jury in the hope that the jury will fix its award to fully compensate deserving plaintiffs. Conversely, defendants might press for disclosure because they expect juries to anchor their awards to the cap figure and award lower damages. Thus, in the absence of a legislative instruction on disclosure of the cap, courts will be forced to decide whether to allow the parties to disclose the cap. When confronted with statutory silence, courts should adopt a policy of nondisclosure. This policy is consistent with the theories that courts have used in upholding the constitutionality of caps. Moreover, it serves strong public policy interests in preventing distortion of jury awards and follows judicial practice on jury disclosure issues in other areas of law. 


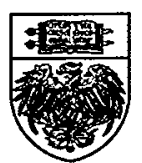

